\title{
第123回日本体力医学会関東地方会
}

\author{
日 時：2001(平成13) 年12月 8 日(十) $13: 00$ - 17:30 \\ 場所：東京学芸大学 芸術館
}

当番幹事：東京学芸大学 健康・スポーツ科学学科 渡 辺 雅 之

\section{1. 陸上競技選手における身体組成と競技成績との関} 連性

鳥居 俊 (早稲田大学人間科学部), 蒼持梨恵子, 池亀 志帆, 江川陽介, 酒井 亮, 館 俊樹, 内藤健二 (早稲 田大学大学院人間科学研究科)

1. The relationship between body composition and athletic performance in track and field athletes. Waseda Univ. Dept. Human Science. Suguru ToriI. Waseda Univ. Graduate School of Human Science. RIEKo KURAMOchI, Shiho IKekame, Yousuke Egawa, Ryou SakaI, Toshiki TACHI ANd KenJi Naitou

競技選手にとって，身体組成や各分節での筋量の分布 は直接的にパフォーマンスに影響する要素である。近年 の生体インピーダンス法に基づく体組成分析装置の発達 により詳細な情報を得ることが可能となり，スポーツ現 場への応用が期待されている．本研究では陸上競技選手 の競技記録と身体組成・各分節の筋量との関連性につい て検討した，対象はW大学陸上競技選手70名（短距離 22 名, 中距離 10 名, 長距離 28 名, 跳躍 7 名, 投擲 3 名) で ある。8 極式高精度体成分分析装置 (Biospace 社製 In Body 3.0) を用いて, 全身, 左右上肢・下肢, 体幹の体 組成や体水分量を算出し, 種目間・男女間で比較すると ともに，短距離では $100 \mathrm{M}$ の, 長距離では $5000 \mathrm{M}$ の記 録との関連性を検討した。

短距離選手は中・長距離選手より身長・体重・脂肪量 が多く，上肢・下肢水分量も体重に一致して多かった.

下肢水分量に対する上肢水分量比は短距離で最も高值で あり，長距離で最も低值であった，男子短距離選手の $100 \mathrm{M}$ の記録と上肢水分量比とは相関し, 上肢水分量比 の高い選手は速い記録を有し，また上肢水分量の左右差 の小さい選手ほど速い記録を有していた。一方，男子長 距離選手では下肢水分量比が高い選手で $5000 \mathrm{M}$ の記録 が速い傾向があった。

投擲選手では上肢の水分量の左右差が見られたが，下 肢水分量の左右差は他種目と差がなかった。

女子短距離選手では男子に比して筋量が少なく脂肪量 が多いほか，上肢筋量比が低かった。

以上の結果より，短距離選手では全体の筋量が多いだ けでなく上肢筋量比を高くし，上肢の左右差を小さくす ることが，長距離選手では下肢筋量比を高くすることが 速い記録を得ることにつながると考えられた。このよう な計測により，競技選手の目標とすべき身体づくりを意 識したトレーニング計画の作成が可能になると期待され る.

\section{2. 四肢・体幹別にみた身体組成の種目特性}

倉持梨恵子, 池亀志帆, 江川陽介, 酒井 亮, 館 俊 樹, 内藤健二(早稲田大学大学院人間科学研究科), 鳥居 俊 (早稲田大学人間科学部)

2. Characteristics of body segmental composition analy. sis in male athlete. Waseda Univ. Graduate School of Human Science. Rieko Kuramochi, Shino IKeKame, Yousuke Egawa, Ryou SaKaI, Toshiki Tachi and KenJI Naitou. Waseda Univ. Dept. Human Science. Suguru TORII

【背景・目的】競技選手にとって身体組成はパフォーマ ンスやコンディションに直接関わる重要な要素である. 近年では Bioelectrical Impedance 法の発達により四肢・ 体幹などの部位別で体水分量の推定が可能となった。そ こで本研究では四肢・体幹別の身体組成を種目別で比較 し，それぞれの特徴を検討することを目的とした。

【方法】対象はW大学体育局に所属する男子選手123名 (アメリカンフットボール26名, ラグビー18名, 水泳 8 名, テニス 8 名, サッカー 5 名, バドミントン 3 名, 陸上： 短距離16名, 中距離 8 名, 長距離 28 名, 投擲 3 名) およ び体育系学科に所属する一般男子学生40名の計163名と した。測定には Biospace 社製 8 極式高精度体成分分析 装置 In Body 3.0 を用いた。

【結果・考察】投擲・ラグビー・アメフト選手では上肢 の水分量比が高く，競技動作における上肢の貢献度が高 いことが反映されていた．短距離選手では脂肪量に対す る筋量が多く, 上肢・下肢・体幹全ての部位で水分量の 体重比が高値を示し, 走力への貢献に関与すると考えら れた。サッカー選手では下肢水分量比が高く，下肢中心 の運動という種目特性が反映された。水泳選手では浮力 を得るための適応として体脂肪率が高い傾向を示し，ま た上肢の水分量が多かったことから競技動作における上 肢の貢献度が反映されたと考えられた．陸上中・長距離 選手では下肢の水分量の体重比が高値を示し，上肢では 低值であったことから長時間の走行における上肢の貢献 度は少なく，エネルギー消費を少なくするための適応で あると考えられた。また種目動作において上肢で左右非 対称な運動をするテニス・バドミントン選手では利き手 側の水分量が $10 \%$ 以上多く，他の種目と大きな差が見ら れた。しかし，投擲選手では左右差の程度が他の種目と 同程度であり，ウエイトトレーニングによって左右対称 に上肢を使う機会が多いことによる適応と考えられた。 


\section{3. 急速反復时届曲運动の持続に伴う上腕二頭筋の筋 形状と筋酸菜動態の变化}

木村有里, 村岡慈歩, 加賀谷淳子 (日本女子体育大学 基礎体力研究所)

3. Changes in muscle architecture and muscle oxygen kinetics during rapid repetitive elbow flexion exercise. Research institute of Japan Women's College of Physical Education. Yuri Kimura, Yoshino Muraoka and Atsuko KaGAYA

【目的】スポーツ活動では, 素早い動作を長く続けるこ とが出来るかどうかが，競技力を決定する場合がある. そこで, 本研究は, 时関節屈曲運動を対象とし, すばや い動作の持続中に，筋形状と筋酸素動態がどのように関 与するかを明らかにし，持続を制限する因子となるかど うかを明らかにすることを目的とした。

【方法】健康な女性5名 $\left(21.1 \pm 0.3\right.$ 歳)に, 时関節を $120^{\circ}$

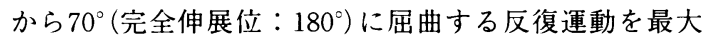
速度で行わせた．負荷は随意最大筋力の $20 \% に$ 相当する 抵抗を屈曲方向のみに与え, 時間は90秒とした。運動時 の上腕二頭筋の筋形状 (SSD-1000, Aloka) と筋酸素動態 （NIRO-300，浜松ホトニクス）の変化を測定し，また筋 電図 (多用途テレメーターシステム WEB-5000：日本光 電)も同様に記録した。

【結果】運動終了時の时関節角速度は運動開始10秒の $18.0 \pm 3.1 \%$ まで低下した。このとき, 时屈曲時と伸展 時の羽状角は運動開始時から運動終了時まで有意な変化 はみられなかった。しかし, 筋腱接合部の移動距離は運 動開始時には $0.7 \pm 0.1 \mathrm{~cm}$ であったが, 運動終了時に は $1.5 \pm 0.2 \mathrm{~cm}$ に有意 $(\mathrm{P}<0.01)$ に増加した。このこと により筋束がより短縮したことが示唆された。しかし， 平均筋電図は運動中一定値を維持した。 また総へモグロ ビン・ミオグロビン $(\mathrm{Hb} / \mathrm{Mb})$ 濃度は運動の持続に伴い 増加した．脱酸素化 $\mathrm{Hb} / \mathrm{Mb}$ 濃度は運動開始後増加し, その後一定值を保ったが, 酸素化 $\mathrm{Hb} / \mathrm{Mb}$ は増加し続け た。

【考察】本研究の結果, 運動を持続すると, 时関節角速 度が低下するとともに, 腱の移動距離が增加したことは, 筋束長がより短縮したことを示す。このことは筋腱複合 体の弾性が低下するためと考えられる. また, 肘関節屈 曲時と伸展時との間の酸素化 $\mathrm{Hb} / \mathrm{Mb}$ と総 $\mathrm{Hb} / \mathrm{Mb}$ に差 が生じたことは，より筋束が短縮したことによって筋か ら血液が還流されたことを示す。しかし，筋内血液貯留 量は增加したので, 筋へ流入する血液量は筋収縮による 還流量を上回ったと考えられる。

以上のことから，すばやい動作の運動を持続すると， 筋束がより短縮しなければならないこと，また，筋内の 血液量が增加することが速度低下の一因となっていると 考えられた。

\section{4. 座位と臥位における同腕引きカの測定}

平岡政憲, 大道 等 (国際武道大学大学院)

4. Muscle strengths of the shoulder and arm system. International Budo University. MASANORI HiRAOKA AND HitosHI ОмıснI

【目的】采道の引き手・釣り手の使い方は勝敗を左右す る.そこで我々は柔道選手の引く力の静的筋力発揮測定 を試みた。本研究は时の関節角度変化による引く力の影 響と、水平方向の肩腕力での座位・臥位姿勢での違いで 力の変化を測定・検討した.

【方法】一般体育大学生13名（体重56 115kg）に垂直・ 水平方向より取っ手付のロープを壁に固定し, 座位・臥 位姿勢で肘角度, 伸展位, 直角位, 屈曲位 3 角度より, 等尺性筋力で 5 秒間測定を行った，また，被験者に，时 の角度を意識させた。

【結果・考察】ロープを垂直に引く力を,「垂直肩腕力」, 水平に引く力を「水平肩腕力」と命名し, 以後「垂直力」 「水平力」と略す，座位・臥位姿勢の引き力測定の平均 值を示す。

\section{伸展位直角位屈曲位}

座位垂直力 $22 \pm 17 \mathrm{~kg} \quad 33 \pm 20 \mathrm{~kg} \quad 26 \pm 16 \mathrm{~kg}$

臥位垂直力 $24 \pm 5 \mathrm{~kg} \quad 32 \pm 6 \mathrm{~kg} \quad 21 \pm 7 \mathrm{~kg}$

座位水平力 $26 \pm 5 \mathrm{~kg} \quad 26 \pm 6 \mathrm{~kg} \quad 24 \pm 5 \mathrm{~kg}$

次に直角位に対する伸展位, 屈曲位の平均割合を示す。

$$
\text { 伸展位屈曲位 }
$$

座位垂直力 $76 \pm 25 \% \quad 81 \pm 18 \%$

臥位垂直力 $79 \pm 14 \% 68 \pm 16 \%$

座位水平力 $106 \pm 33 \% \quad 96 \pm 28 \%$

座位垂直力, 臥位垂直力は直角位, 座位水平力は伸展 位の関節角度時が高值であった．臥位垂直力と座位水平 力の比較は，臥位垂直力は下肢・体幹筋の影響を抑える ことで，関節角度の違いが見られた。一方，座位水平力 は下肢筋の影響を抑えたことで, 関節角度での違いは見 られなかった。「引く力の时関節角度で, 直角位状態 が一番力発揮されると言われるが，座位垂直力と臥位垂 直力はその傾向が見られた。しかし，座位水平力は时の 関節角度に関係なく力発揮されている傾向であった。 


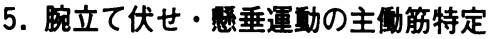 〜上肢回旋位との関連で〜}

漢那朝伸, 大道 等 (国際武道大学大学院)

5. Functional Anatomy of Chin-up Motions on a High Bar and push-up from the Electromyographic View. The International Budo University. TомоNоBU KaN-NA AND Нiтоsні ОнміснI

【目的】鉄棒の紫垂運動、腕立て伏せを行った際に、时関 節屈曲作用に, (1)腕橈骨筋(2)上腕二頭筋(3)上腕三頭筋(4) 三角筋はどのように作用するのかを検討した。

【方法】被検者一般体育大学生(1)・順手, 逆手で鉄棒懸 垂運動, 計 2 試行(2)内旋位, 外旋位で腕立て伏せ, 計 2 試行(3) ・傾斜面上で腕立て伏せ (傾斜-15\%・-10\%・ $0 \% \cdot 10 \% \cdot 15 \%)$ 計 5 試行. 各動作時の 4 筋の筋放電を 記録した。ここで得られた結果を静的MVCの百分率表 にした

【結果】鉄棒懸垂では順手, 逆手の両試行とも 4 筋に放 電が見られた：その振幅量は4筋とも50\%〜100\%であり， 逆手の方が大きな值を示した．内旋位，外旋位腕立て伏 せにおいては腕橈骨筋，上腕三頭筋が50～100\%であり， 上腕三頭筋は内旋位, 外旋位共に $100 \% \mathrm{MVC}$ であった。 傾斜面上では，傾斜がー $15 \% \rightarrow 0 \% \rightarrow 15 \%$ と上るに連れて 腕橈骨筋の振幅量が $60 \% \rightarrow 40 \% \rightarrow 30 \%$ と減少していっ た. 上腕三頭筋は肘関節最大屈曲位に50２0\%に減少す るが, 伸転位から屈曲, 屈曲位から伸展にかけては $100 \%$ MVC の振幅量を示した，上腕二頭筋，三角筋は 2 試行とも終始20４0％の振幅量であった。

【考察】1腕立て伏せの时関節屈曲, 伸展動作では上腕 三頭筋が主働する，肘関節伸展、肩関節屈曲動作に腕橈 骨筋, 三角筋が協動し, 腕橈骨筋 (肩関節外展位伸展吕 ら屈曲にかけて三角筋) は伸張性筋収縮を行う。手関節 背屈角度が増加, 減少することにより, 腕橈骨筋の筋発 揮量も増加及び, 減少するということが傾斜面上腕立て 伏せによって示唆された $(90$ 度 $>90$ 度 $>90$ 度 $\uparrow)$.

2 鉄棒の懸垂挙上動作, 腕立て伏せは时関節屈曲と肩 関節伸展の複合動作である。(下りの懸垂では肘関節伸 展と局関節屈曲の複合)

3 上腕二頭笳と上腕三頭筋は懸垂動作においては協㗢 筋である。

4 腕橈骨笳と上腕二頭筋は时屈曲動作で相補的協働筋 である事が EMG から明示された。 回外位では上腕二頭 筋、回内位では腕橈骨筋が主動する。

5 懸垂正仕事に上腕三頭筋と上腕二頭筋 (and/or 腕橈 骨筋) は共に短縮性収縮, 負仕事では伸張性収縮を行う ことが示唆された。

\section{6. サッカーのヘディングスキルと重心運動}

北湯口純，藤村鉄平，大道 等 (国際武道大学)

6. Analysis of The body's center of gravity in soccer heading-skill from the biomechanical view. International Budo University. Jun Kitayuguchi, Teppei HuJimura AND Hitoshi ОнмichI

【目的】サッカーヘディング動作の重心運動を压力板 (キスラー社製)を用いてバイオメカニクス的視点から解 析するとともに、その動作をキネマティクスに解析する。 【対象者】サッカー経験者 4 名〔競技歷 $5 \sim 15$ 年〕を上 級者群 (以下 $A$ 群), サッカーの専門的指導を一切受けて いないサッカー未経験者 4 名を初級者群（以下B群）と してスキル水準の分別をし, 計 8 名 $(22.1 \pm 1.6$ 歳)を被 唡者とした。

【方法】 A 群と B 群に2種(シュート，クリア)のヘディ ングを压力板上で行わせた。被唡者は圧力板上に半身で 立ち，筒状の簡易ボール落下装置 $(5.5 \mathrm{~m}$ の高さから転が され，4.1 mの高さから落下する)から落下してくるボー ルをへディングした.

【結果】シュートの上方重心速度 (ピーク值)は $\mathrm{A}$ 群が $47.8 \pm 16.8 \mathrm{~cm} / \mathrm{s}$, B 群は $29.7 \pm 33.1 \mathrm{~cm} / \mathrm{s}$, 前方重心速 度は $\mathrm{A}$ 群が $37.0 \pm 6.5 \mathrm{~cm} / \mathrm{s}$, B 群は $43.8 \pm 23.7 \mathrm{~cm} / \mathrm{s}$ であった。クリアの上方重心速度は $\mathrm{A}$ 群が $116.2 \pm 20.4$ $\mathrm{cm} / \mathrm{s}, \quad B$ 群は $88.9 \pm 32.8 \mathrm{~cm} / \mathrm{s}$, 前方重心速度は $\mathrm{A}$ 群が $38.7 \pm 15.4 \mathrm{~cm} / \mathrm{s}$, B 群は $43.0 \pm 16.3 \mathrm{~cm} / \mathrm{s}$ であった。 シュートの上方重心変位の総和 ( $\mathrm{P}-\mathrm{P}$ 值) は $\mathrm{A}$ 群が 8.6 $\pm 4.5 \mathrm{~cm}, \mathrm{~B}$ 群は $5.9 \pm 5.6 \mathrm{~cm}$, 前方は A 群が $18.6 \pm 2.4$ $\mathrm{cm}, \mathrm{B}$ 群は $15.5 \pm 9.0 \mathrm{~cm}$ であった。クリアの上方重心 変位総和は $\mathrm{A}$ 群が $21.9 \pm 5.5 \mathrm{~cm}, \mathrm{~B}$ 群は $18.2 \pm 7.5 \mathrm{~cm}$, 前方は $\mathrm{A}$ 群が $20.2 \pm 7.6 \mathrm{~cm}, \mathrm{~A}$ 群は $18.1 \pm 4.5 \mathrm{~cm}$ であ つた。キネマティクスな動作の違いとして初級者群は ボールインパクト直前に目を閉じ，ボールを頭頂，側頭 部で打っていた.

【考察】シュート, クリアともに両群のスキル水準を決 定する有意な差は認めら机なかったが，そのスキルを重 心基本変量から得られる波形, 振幅、ピーク值などから 記述することが可能となる傾向が見られ，この記述と並 行してへディング動作における身体各部位の動きをキネ マティクスに記述していく必要性が示唆された。 
7. 傾斜トレッドミルの試作

〜㑯斜面歩行における下肢筋の放宣特性〜

山本義哲, 大道 等 (国際武道大学大学院)

7. A newly designed treadmill equipped on the slope mounts. International Budo University. Yoshiaki Yamaмото AND НiтоsнI ОнміснI

【目的】電動式トレッドミルは, バイオメカニクス研究 において応用されている. しかしその研究の多くは, 平 地における位置移動運動に焦点がおかれ，坂道における 歩・走の研究は少なかった. 本研究では, 上り・下り歩 行両者の実現を金属製の台を数組用いることで可能に し，トレッドミルを新たに試作した． 2 台の小型圧力板 上に傾斜台を設置しそその上にトレッドミルを設置した. そのことにより正負 3 種類の傾斜角 $( \pm 5,10,15 \%)$ の 傾斜で歩・走ができるようになり，このシステムを用い ることで身体重心の上下動が首尾よく測定できるように なり，平地との比較ができるようになった。

【方法】試作したトレッドミル上で一般体育大学生に平 地傾斜 $0 \%$ と上り・下り傾斜 $10 \%$ で歩行を時速 $3,7 \mathrm{~km}$ で行わせた。速度の違いにより下肢の筋にどのような変 化が起こるか、表面筋電図電極を外側広筋・内側広筋 ・ 大腿直筋 ・大腿二頭筋・腓腹筋の 5 䇢所に $2 \mathrm{~cm}$ 間隔で装 着した。

【結果】各筋の $100 \% \mathrm{MVC}$ に対しての百分率を下表に 示した，速度が約 2 倍速くなることで各筋の筋出力が平 地20 30\%増加し，上りでは10４0\%増加した．下りで も10 40\%増加し, 速度の上昇によって各筋の筋出力も 増加することが見られた，下表に各筋の筋放電振幅を， 静的 MVC の百分率を示す。（\%)

$$
\begin{array}{lll}
0 \% & 10 \% & -10 \%
\end{array}
$$

$\begin{array}{lllllll}\mathrm{km} / \mathrm{h} & 3 & 7 & 3 & 7 & 3 & 7\end{array}$

外側広筋 $6070 \quad 6090 \quad 5090$

内側広筋 $6090 \quad 6090 \quad 5090$

大腿直筋 $\quad \begin{array}{llllll}50 & 70 & 70 & 80 & 60 & 70\end{array}$

大腿二頭筋 $\quad \begin{array}{llllll}50 & 70 & 80 & 80 & 70 & 80\end{array}$

腓腹筋 $\quad 7080 \quad 7080 \quad 7080 \%$ 